\title{
India's Horticultural Export Markets: Growth Rates, Elasticities, Global Supply Chains, and Policies
}

\author{
M. B. Dastagiri \\ National Academy of Agricultural Research Management, Hyderabad, India \\ Email: dgiri_mb@yahoo.co.in
}

How to cite this paper: Dastagiri, M.B. (2017) India's Horticultural Export Markets: Growth Rates, Elasticities, Global Supply Chains, and Policies. Modern Economy, 8, 847-864.

https://doi.org/10.4236/me.2017.87059

Received: May 8, 2017

Accepted: July 7, 2017

Published: July 12, 2017

Copyright $\odot 2017$ by author and Scientific Research Publishing Inc. This work is licensed under the Creative Commons Attribution International License (CC BY 4.0).

http://creativecommons.org/licenses/by/4.0/

\section{(c) (i) Open Access}

\begin{abstract}
Digital Economy, Ecommerce and fortune economy depend on export market information. Globally, horticulture industry is one of the noteworthy sectors. India is major fruit and vegetable basket of the world. This study estimates exports, price growth rates, elasticity's, identifies major destinations and trace global supply chains for horticultural commodities. The study period is 19901991 to 2012-2013. Compound annual growth rates, elasticities and instability index are the methodological tools employed. All fruits', vegetables' and flowers' elasticities are shown to be elastic excluding walnut \& mushrooms. Tea's \& Coffee's elasticities are elastic. The supply chain channels to Europe, UK, US and Middle East highly developed and no middlemen involved. In case of South Asia, Africa and South East Asia, lengthy and middlemen involved. Global supply chain model must be connecting directly producers with exporters and importers or consumers of importing countries. This is possible digitalization of data and single window processing.
\end{abstract}

\section{Keywords}

Export Markets, Growth Rates, Elasticities, Global Supply Chains, Policies

\section{Introduction}

Global Horticulture Market Outlook 2015 projects that horticulture industry plays vital role in the future. The globe has initiated measures to support this industry. In 2011, global fruits and vegetables production were 548 million tonnes and 990 million tonnes respectively. And the global floriculture industry size was around USD 109 billion [1].

Globalization has witnessed the focus on integration of developing country firms geographically with PAN world with supply networks or commodity 
chains. These global supply chain linkages help to connect developing countries' firms with developed countries' suppliers and customers. Gereffi [2] [3], emphasises not only that independent companies in different countries are linked together in trading relationships, but also that the chain should be considered as a network governed to a large extent by key agents within it. Watts's paper focused on the trade in fresh vegetables and said that this sector has become one of the most vibrant sectors in international trade, and during the 1990s, imports of fruit and vegetable products by EU countries surpassed all other categories of agricultural products (Wattsl 994).

Gereffi [3] reported GCCs [Global Commodity Chains] novel in increasingly organizing international production and trade in strategic decision making and economic networks at global scale by industrial and commercial firms. Gereffi [2] classified the commodity chains are producer-driven and buyer-driven. Producer-driven commodity chains are governing by transnational firms and buyer-driven commodities govern by retailers, importers and brand-name companies. These firms link overseas factories and traders with evolving product niches in their main consumer markets.

India is one of the largest agrarian economies of the world. In the context of economic liberalization, it promotes export led growth. The Indian National Agriculture Policy (NAP) focuses more on demand driven agricultural growth in domestic and export markets. Of late, WTO trade liberalization and multilateral negotiations also focus more on international agricultural commodity markets in the light of improvement of market access and limitation of export subsidies.

Horticulture marketing define as finding out what your customers want and supplying it to them at a profit therefore involves: identifying buyers, understanding what they want in terms of products and how they want to be supplied, operating a production-marketing chain that delivers the right products at the right time and making enough profit to continue to operate.

Horticultural sector contributes $54 \%$ of agricultural Exports and $28 \%$ of AgGDP in India. Over the last decade this sector grown at the growth rate of 3.6 percent. NHB, 2011 reported that India is second largest producer of fruits and vegetables in the world next only to China. This tremendous production potential offers India's greater opportunities for exports. India produced in 2010-11, 146.55 MTs of vegetables and 74.88 MTs of fruits. And its requirement is 175.2 MTs vegetables and 74.40 MTs fruits. In 2011-12, India exported vegetables and fruits worth Rs. 4801.29 crores. The consumption basket is changing towards fruits and vegetables. National Horticultural Mission started in 2005, Foreign Trade Policy (2004-09) advocating to boost export growth and promotion of horticultural products. XI \& XII Plans also emphasizing accelerated horticultural growth.

India is one of the world's leading producers of finest tea 23 per cent share by volume in 2013. Its contribute 12 per cent share in world tea exports in 20132014. The CIS countries accounted for 19.8 per cent of total exports in 20132014 with US\$ 152.46 million. India registered exports of 225.7 million $\mathrm{kg}$. for 
approximately 78 per cent of total exports during 2013-2014 [4]. In 2013-2014, the Russian federation was the topmost importer of Indian tea, followed by UAE and Iran respectively.

Coffee Board, 2014 reported that India ranked in coffee production seventh largest in the world and third largest Asia. India exported coffee during 20132014, 313,025 metric tonnes and earned foreign revenue 793.22 US\$ million. India exports coffee to over 45 countries, over 50 per cent of to Europe. Italy is the largest importing more than 25 per cent from India [5].

We are living in multi-speed world economies. Horticultural commodities play significant role in living economics. World Development Report [6] reported that markets are central to the lives of poor people and World Bank, World Development Report [7] framed institutions that support the development of markets.

UNCTAD [8] study revealed that India's exports to world are income elastic and found that $1 \%$ decline in GDP growth of world will lead to $1.88 \%$ decline in India's growth of exports. Singh and S. K. Singla [9] found from their study (1992 to 2006) that India has been unable to diversify its exports as well as export destinations. Export from India has experienced instability primarily in the developing countries. Demand for India's exports was found to be elastic to both relative prices and income of the importing countries. Traill [10] predicts that by 2015 supermarket's share of the retail food market will reach 61\% in Argentina, Mexico, and Poland, 67\% in Hungary and 76\% in Brazil. IFPRI's [11] research shown that agricultural Market reforms liberalization programs adopted by many developing countries in the past had limited success in developing private, efficient, and competitive agricultural markets. Dastagiri and Immanuelraj [12] advocates reforms needed to shift Indian farming from traditional farming to an agribusiness sector and develop linkages farmers to super markets and export markets is a key driver for industrialization of agriculture.

Alberto and Stefano [13] estimated import price demand elasticity in the destination markets of Italian exports found that Italy has a relatively low elasticity of substitution in main specialization sector (machinery and equipment), while has higher substitution elasticity for traditional goods like textiles, jewelry and leather. Reardon and Hopkins [14]; Minton (2008) found that super markets and retailers competing om price, convenience, quality of the products and safety. Mithofer et al. [15] found that smallholders were linked to the export market by middlemen in Kenya. Galanopoulos et al. [16] reported that though Mediterranean countries are traditional growers of fruit and vegetables but unable to competitive in the global market. Dastagiri et al. [17] estimated and found that for all vegetables the NPC is less than 1 indicating they are competitive in the international markets. Lenné \& Ward [18] found that the export vegetable subsector as a role model for improving the efficiency, growth and economic value of domestic vegetable marketing systems in East Africa. Dastagiri et al. [19] reported that most of the Indian horticultural commodity markets were operating efficiently and producer-consumer was the most efficient channel. Diego et al 
[20] found in Niamey, Niger for market retailers net profit (NP) for amaranth and lettuce on marketplace, whereas the NP of cabbage and tomato strongly depended on season and marketplace.

This paper examines the position of Indian producers and exporters in the horticultural export trade from the perspective of the global supply chain analysis. There are limited studies on market research of horticulture commodity global supply chains and identification of major global markets. This study analyses Indian horticultural commodities export markets linking to global supply chains and price trends, elasticity's and instability \& identification of their destinations. Finally, the study will suggest multispeed strategies for improvement of global supply chains, prices, production, and trade.

The Specific Objectives are:

1) To analyze exports price growth rates of India's horticultural commodities.

2) To estimate export elasticity's for Indian fruits, vegetables, flowers and Tea \& Coffee.

3) To identify major destinations for horticultural commodities and their share in world horticultural exports.

4) To trace India's horticultural commodities Global Supply chains.

5) To suggests polices and strategies for boosting Indian horticultural exports and foreign earnings.

\section{Methodology}

The study analyses the marketing of horticultural commodities exports with global supply chain perspective. India's major export horticultural commodities were selected. It includes fruits, nuts, vegetables, flowers, coffee and tea. Study Period is 1990-1991 to 2012-2013. Data on quantity, values, and prices of exports, international prices and destinations of fruits, vegetables, flowers coffee and tea were collected. India is exporting these commodities to maximum 130 countries. Data sources are Agricultural Produce Export Development Authority (APEDA), Directorate General of Commercial Intelligence (DGCIS),National Horticultural Board (NHB), FAO Stat, Centre for monitoring on Indian economy (CMIE), Foreign Trade Year Book, Planning commission reports, National Bank for Agricultural and Rural Development (NABARD), EXIM Bank, export companies, Tea \& Coffee Boards. Compound annual growth rates and trends of quantity exports, prices, and price elasticity's of exports were estimated. For each commodity, the countries classified in to the top 10 countries based on major share of exports and rest as other countries. Finally top 3 countries of India's exports for each commodity are identified. India's horticultural commodities global supply chains traced with the help of experts of export companies, growers and literature. The compound growth rates, price elasticity's, instability index of exports were estimated using the following formulae's.

Growth rate formulae: [21]

The growth rates were calculated by fitting Exponential function for exports, prices etc for the period 1990-1991 to 2012-2013. 


$$
Y_{t}=Y_{0}(1+r)^{\mathrm{t}}
$$

Assuming multiplicative error term in the Equation (1), model may be linearized by logarithmic transformation

$$
\ln Y_{t}=A+B t+€
$$

where, $\mathrm{A}\left(=\ln \mathrm{A}_{0}\right)$ and $\mathrm{B}(=\ln (1+\mathrm{r}))$ are the parameters to be estimated by ordinary least square regression, $t=$ time trend in year, $r=\exp (B)-1$

\section{Price elasticity of exports formulae:}

$$
\sum \mathrm{P}_{\mathrm{e}}=\% \text { change in quantity exports } / \% \text { change in price }
$$

The percentage change in quantity exports is $\% \Delta Q$, and the percentage change in price is $\% \Delta P$. We calculate $\% \Delta Q$ as $\Delta Q / Q_{a v e}$ and we calculate $\% \Delta P$ as $\Delta P / P_{a v e}$, so we calculate the price elasticity of exports as $\left(\Delta Q / Q_{a v e}\right) /\left(\Delta P / P_{a v e}\right)$.

Instability Index formulae:

$$
\text { Coefficient of Variation }=\frac{\text { Standrd Deviation }}{\text { Mean }} * 100
$$

\section{Results and Discussion}

\subsection{Exports, Price Growth Rates, Elasticity's, Destinations, of Fruits, Vegetables \& Flowers}

\subsubsection{Exports, Price Growth Rates}

The quantity of exports and export price growth rates (\%) of India's fruits, vegetables and flowers during 1990-2012 are shown in Table $1 \&$ Table 2. The export growth rates of fruits such as Banana, Mango, Pomegranate, Grapes are 19.6\%, $5.8 \%, 19 \%, 14.4 \%$ respectively. Mango and Grapes exports are stable as their coefficient of variation is less than 100 percent whereas Banana and pomegranate are instable as their coefficient of variation is more than 100 percent. The export growth rates of fruits such as Mango, Pomegranate, and Grapes are more during 1990-2000 compared to 2000-2012.

Whereas export growth rates of vegetables such as Onion, Gherkin, Green chilies, potato are $8.4 \%, 23 \%, 5 \%, 13.1 \%,-28.9 \%$ respectively. The export growth rate for Rose is $7.8 \%$ and walnut is $-8 \%$. During 2000-2012, all variables growth rates of Green Chillies are negative because of low export prices and lack of demand during this period. Onion and Gherkins exports are stable as their coefficient of variation is less than 100 percent whereas Green chillies and Potato exports are instable as their coefficient of variation is more than 100 percent. It was found that the growth rates are positive for fruits, vegetables and flowers and for mushrooms and walnut are negative. The price growth rates of fruits such as Mango, Pomegranate, Grapes, Banana are 3.5\%, 6.7\%, 6.2\%, 1.7\% respectively. Similarly, vegetables price growth rates are Onion 6.1\%, Gherkin 3.7\%, Green chilies $0.8 \%$, Potato $3.7 \%$, and Mushrooms $5.4 \%$. The Rose price growth rate is $30.6 \%$ and walnut is $6.5 \%$. The study found that the price growth rates of all fruits, vegetables and flowers are positive and high.

It was found that the export growth rates of fruits, vegetables and flowers are 
positive except mushrooms and walnut. Contrastingly price growth rates for all commodities in the export destinations were positive and high. The prices of fruits, vegetables and flowers are stable as their coefficient of variation is less than 100 percent. The study concludes that all commodities quantity export growth rates more than price growth rates except walnut and mushrooms.

\subsubsection{Export Elasticity's}

How responsive are export quantities to a change in international prices is of direct relevance in international economics. Export price elasticities are signals for exporters to increase or decrease their exports as it indicates exports responsiveness to changes in price.

The India's fruits, vegetables and flowers export elasticity's during 1990-2012 (\%) are shown in Table $1 \&$ Table 2. The elasticities of Fruits such as Banana, Mango, Pomegranate, Grapes are 4.58\%, 1.38\%, 1.31\%, 1.31\% respectively. The export elasticity's of Vegetables are Onion 1.15\%, Gherkin 1.84\%, Green chilies $3.98 \%$, Potato $1.42 \%$. The Rose export elasticity is $0.59 \%$ and walnut is $6.68 \%$.

It was found that banana has among fruits high export elasticity (4.38) and Green Chillies among vegetables have high (3.98). All elasticity's of fruits, vegetables and flowers are elastic whereas walnut and mushrooms are inelastic.

\subsubsection{Export Destinations}

India's fruits, vegetables and flowers export destinations and their share in the world exports during 2000-2012 are shown in Table $1 \&$ Table 2. India exports these commodities to ranges from 40 to 130 countries of the world. For each commodity, the countries classified in to the top 10 countries which accounted major share of exports and rest as other countries. Finally, it was found that the top 3 countries which accounted $60 \%$ to $78 \%$ of India's exports.

The major destinations for Indian mango is UAE (37.20\%), Bangladesh (32.66\%), Saudi Arabia (9.46\%), for Grapes; Bangladesh (29.02\%), Netherland (18.29), United Kingdom (15.3\%), for Banana; Nepal (78.28\%), UAE (6.17\%), Maldives (3.13\%). for Pomegranate; UAE (48.52\%), Bangladesh (12.76\%), Saudi Arabia (8.30\%). The major destinations for walnut are Nepal (13.08\%), United Kingdom (11.52\%), France (10.18\%).

The major destinations for Indian vegetables are; for Potato; South Africa (29.75\%), UAE (11.93\%), Pakistan (12.61\%), for Onion; Bangladesh (29.77\%), Maldives (21.64\%), UAE (15.92\%), for Green Chillies; United Kingdom (16.30\%), Pakistan (13.54\%), UAE (12.19\%), for Gherkins; USA (20.32\%), France (17.75\%), Spain (14.88\%), for Mushroom; USA (80.93\%), Israel (12.65\%), Russia (1.27\%). Netherland (26.34\%), Ethiopia (21.03\%), UAE (9.43\%) are he major destinations for India's rose are.

The study found that the India is the major shopping basket for world fruits and vegetables. India's $65 \%$ - $90 \%$ fruits and $50 \%$ to $65 \%$ vegetables exports in fresh products go to West Asia and East European markets. The 53\% exports of Gherkins, 94\% Mushrooms going to the USA, United Kingdom, France, Spain, 
Table 1. Fruits of destination, exports, prices and elasticity's [22] [23] [24] [25].

\begin{tabular}{|c|c|c|c|c|c|}
\hline Crop & $\begin{array}{l}\text { Top three } \\
\text { promising countries }\end{array}$ & $\begin{array}{c}\% \text { of } \\
\text { exports }\end{array}$ & $\begin{array}{c}\text { Price Growth rate \& CV } \\
1990-91 \text { to } 2011-12\end{array}$ & $\begin{array}{c}\text { Export Qty Growth rate \& CV } \\
1990-91 \text { to } 2011-12\end{array}$ & $\begin{array}{c}\text { Elasticity \% change } \\
\text { from } 1990-91 \text { to } 2011-12\end{array}$ \\
\hline \multirow{3}{*}{ BANANA } & Nepal & 78.3 & $1.1(83.54)$ & $19.6(166.15)$ & 4.58 \\
\hline & United Arab Emirates & 6.2 & & & \\
\hline & Maldives & 3.7 & & & \\
\hline \multirow{3}{*}{ GRAPES } & Bangladesh & 29.0 & $6.2(37.26)$ & $14.4(97.06)$ & 1.31 \\
\hline & Netherland & 18.3 & & & \\
\hline & United Kingdom & 15.3 & & & \\
\hline \multirow{3}{*}{ Mango } & United Arab Emirates & 37.2 & $3.5(34.93)$ & $5.8(44.08)$ & 1.35 \\
\hline & Bangladesh & 32.7 & & & \\
\hline & Saudi Arabia & 9.5 & & & \\
\hline \multirow{3}{*}{ Pomegranate } & United Arab Emirates & 48.5 & $6.7(58.02)$ & $19.0(108.30)$ & 1.31 \\
\hline & Bangladesh & 12.8 & & & \\
\hline & Saudi Arabia & 8.3 & & & \\
\hline \multirow{3}{*}{ Walnut } & Nepal & 13.1 & $6.5(36.93)$ & $-8.1(58.00)$ & -6.68 \\
\hline & United Kingdom & 11.5 & & & \\
\hline & Spain & 9.1 & & & \\
\hline
\end{tabular}

Source: Food and Agricultural Organization (FAO). 2014 [25] \& Agricultural Produce Export Development Authority (APEDA) 2014 [22].

Table 2. Vegetables and flowers of destination, exports, prices and elasticity's.

\begin{tabular}{|c|c|c|c|c|c|}
\hline Crop & Country & $\begin{array}{c}\text { Total \% } \\
\text { of Qty }\end{array}$ & $\begin{array}{c}\text { Price Growth rate \&CV } \\
1990-91 \text { to } 2011-12\end{array}$ & $\begin{array}{l}\text { Qty Growth rate \&CV } \\
1990-91 \text { to } 2011-12\end{array}$ & $\begin{array}{c}\text { Elasticity \% change } \\
\text { from } 1990-91 \text { to } 2011-12\end{array}$ \\
\hline \multirow{3}{*}{ Onion } & Bangladesh & 29.8 & $6.1(39.83)$ & $8.4(69.08)$ & 1.15 \\
\hline & Malaysia & 21.6 & & & \\
\hline & United Arab Emirates & 15.9 & & & \\
\hline \multirow{3}{*}{ Potato } & Sri Lanka & 44.2 & $5.1(65.90)$ & $13.1(161.49)$ & 1.42 \\
\hline & Nepal & 16.8 & & & \\
\hline & Maldives & 9.2 & & & \\
\hline \multirow{3}{*}{ Green Chilly } & United Kingdom & 16.3 & $0.8(26.94)$ & $5.0(125.14)$ & 3.98 \\
\hline & Pakistan & 13.5 & & & \\
\hline & United Arab Emirates & 12.2 & & & \\
\hline \multirow{3}{*}{ Gherkins } & United States & 20.32 & $3.7(22.77)$ & $23.0(70.54)$ & 1.84 \\
\hline & France & 17.75 & & & \\
\hline & Spain & 14.88 & & & \\
\hline \multirow{3}{*}{ Mushroom } & United States & 80.9 & & $5.4(151.1)$ & \\
\hline & Israel & 12.6 & & & \\
\hline & Russia & 1.3 & & & \\
\hline \multirow{3}{*}{ Rose } & Netherland & 25.34 & -25.1 & 28.9 & \\
\hline & Ethiopia & 21.03 & & & \\
\hline & United Arab Emirates & 9.43 & & & \\
\hline
\end{tabular}

Source: Food and Agricultural Organization (FAO). 2014 [25]. 
Israel and Russia. Netherland, Ethiopia and UAE are the major destinations for Indian rose. The major destinations (40\%) for Walnut is Nepal, UK and France.

\subsection{Exports and Overseas Prices Growth Rates of Tea and Coffee}

The quantity of exports and export price growth rates (\%) of India's Tea and Coffee during 1990-2012 are shown in Table 3. The export growth rates of Tea and Coffee are $0.7 \%, 4.9 \%$ respectively. Tea exports are stable as their coefficient of variation is less than 100 percent but Coffee exports are unstable as coefficient of variation more than 100. Singh and S. K. Singla [12] found from their study (1992 to 2006) that exports from India have experienced instability primarily in the developing countries. The price growth rates of Tea and Coffee are $4.8 \%$, $7.7 \%$, respectively. It was found that the prices of Tea Coffee are stable as their coefficient of variation is less than 100 percent. The study concludes that Tea and Coffee commodities quantity export growth rates less than price growth rates.

\section{Country Wise Exports and Overseas Prices Growth Rates}

\section{1) Coffee}

The growth rates of exports and prices of Coffee for major countries are in Table 4. During 1996-1997 to 2013-2014, the export growth rates shows that Japan has the highest growth rate (18.3) followed by Newzeland (9.1), Belgium (8.7), Italy (7.0), and France (4.6). Whereas price growth rates shows that Japan has highest growth rates (5.6), followed by Belgium (4.8), Greece (4.2), Italy (4.1) and Newzeland (3.5). This indicates that India should export Coffee to these overseas markets. The exports and prices are stable in these countries.

2) Tea

The growth rates of exports and prices of Tea for major countries are in Table 5. During 1996-1997 to 2013-2014, Australia has the highest growth rate (61.0) followed by Japan (48.6), Netherland (34.2), and USA (23.9). The exports are unstable. For the same period the price growth rates shows that USA has the highest growth rates (10.1), followed by Japan (8.3) and Russia (6.9). The prices are stable. This indicates that India should export Tea to these overseas markets.

\section{3) Export Elasticity's}

In international Economics How responsive is export quantities to a change in international prices are of direct relevance. Export price elasticity's are signals for exporters to increase or decrease their exports as it measures indicates exports responsiveness to changes in prices.

The export elasticity's of India's Tea and Coffee during 1990-2012 (\%) are shown in Table 6. During this period the export elasticity's of Tea and Coffee are $13.5 \%, 61.4$ respectively which are highly elastic. This indicates that Tea and Coffee are highly competitive in overseas markets.

\subsection{Countrywise Tea \& Coffee Elasticity's}

The Coffee export elasticity's for different overseas markets are in Table 7. Dur- 
Table 3. The exports and international price growth rates of India's Tea \& Coffee during 1990-2012 (\%).

\begin{tabular}{|c|c|c|c|c|c|c|c|c|c|c|}
\hline \multicolumn{11}{|c|}{ Exports Qty, Value and Price Growth Rates during 1990 to 2012} \\
\hline \multirow[t]{2}{*}{ Crop } & & \multirow{2}{*}{$1990-1991$} & \multirow[t]{2}{*}{$2000-2001$} & \multirow[t]{2}{*}{ 2011-2012 } & \multicolumn{2}{|c|}{$1990-1991$ to $2000-2001$} & \multicolumn{2}{|c|}{$\begin{array}{l}2000-2001 \text { to } \\
2010-2011\end{array}$} & \multicolumn{2}{|c|}{$\begin{array}{l}1990-1991 \text { to } \\
2011-2012\end{array}$} \\
\hline & & & & & $\mathrm{cv}$ & Growth rate & $\mathrm{cV}$ & Growth rate & $\mathrm{cv}$ & Growth rate \\
\hline \multirow[t]{3}{*}{ Tea } & Qty. & 202 & 187.43 & 233.4 & 13.0 & -0.8 & 10.0 & 2.5 & 11.4 & 0.7 \\
\hline & Value & 1074.82 & 1788.71 & 3174.5 & 34.1 & 5.8 & 26.4 & 6.6 & 36.4 & 5.6 \\
\hline & Price & 5.320891 & 9.54335 & 13.6011 & 27.5 & 6.7 & 16.8 & 4.0 & 28.3 & 4.8 \\
\hline \multirow[t]{3}{*}{ Coffee } & Qty. & 85.98 & 184.9 & 222.86 & 168.5 & 8.9 & 10.3 & 2.1 & 146.2 & 4.9 \\
\hline & Value & 253.32 & 1184.87 & 2912.07 & 57.9 & 18.7 & 37.9 & 10.5 & 49.7 & 13.0 \\
\hline & Price & 2.946267 & 6.408167 & 13.0668 & 53.5 & 9.0 & 34.6 & 8.2 & 44.1 & 7.7 \\
\hline
\end{tabular}

Qty (000 tonnes), Value (Lakh Rs.), Price (Lakh Rs). Source: Food and Agricultural Organization (FAO). 2014 [25].

Table 4. Country wise Coffee exports and price growth rate during 1990-2012 (\%).

\begin{tabular}{|c|c|c|c|c|c|c|c|c|c|c|c|c|}
\hline \multirow{3}{*}{ Country } & \multicolumn{12}{|c|}{ Coffee Growth rates and cv } \\
\hline & \multicolumn{4}{|c|}{$1996-1997$ to $2003-2004$} & \multicolumn{4}{|c|}{$2003-2004$ to $2013-2014$} & \multicolumn{4}{|c|}{$1996-1997$ to $2013-2014$} \\
\hline & Qty & $\mathrm{Cv}$ & Price & $\mathrm{Cv}$ & Qty & $\mathrm{cv}$ & Price & $\mathrm{cv}$ & Qty & $\mathrm{Cv}$ & Price & $\mathrm{cv}$ \\
\hline GERMANY & 1.8 & 18.0 & 0.8 & 0.6 & 3.0 & 29.5 & 0.4 & 35.7 & 2.5 & 29.5 & 1.5 & 40.9 \\
\hline GREECE & 6.8 & 29.4 & -7.9 & 0.5 & 2.8 & 17.7 & 13.6 & 37.7 & 4.4 & 30.3 & 4.2 & 42.4 \\
\hline FRANCE & 22.7 & 49.0 & -9.1 & 0.5 & -6.5 & 42.1 & 12.9 & 40.9 & 4.6 & 41.6 & 3.3 & 44.3 \\
\hline BELGIUM & 21.0 & 37.7 & -7.3 & 0.5 & 0.9 & 32.8 & 14.1 & 41.7 & 8.7 & 35.2 & 4.8 & 48.8 \\
\hline KUWAIT & 4.5 & 25.7 & -6.5 & 0.8 & 4.3 & 19.7 & 10.9 & 34.7 & 4.4 & 84.6 & 3.3 & 38.1 \\
\hline ITALY & 9.1 & 23.2 & -7.1 & 0.5 & 5.6 & 21.9 & 12.6 & 37.5 & 7.0 & 36.2 & 4.1 & 41.8 \\
\hline JAPAN & -12.3 & 38.0 & -7.5 & 0.6 & -22.3 & 86.7 & 15.9 & 42.4 & -18.3 & 42.8 & 5.6 & 44.0 \\
\hline NETHERLAND & 2.2 & 29.4 & -8.6 & 0.6 & -7.9 & 48.5 & 12.3 & 39.1 & -3.9 & 53.3 & 3.2 & 47.0 \\
\hline NEW ZEALAND & 13.9 & 69.0 & -6.1 & 0.6 & 5.8 & 25.2 & 10.8 & 36.2 & 9.1 & 44.3 & 3.5 & 41.3 \\
\hline Others 131 country & -2.2 & 10.0 & -3.9 & 0.6 & 2.1 & 20.1 & 14.2 & 37.2 & 0.3 & 40.9 & 6.4 & 41.2 \\
\hline
\end{tabular}

Qty (000 tonnes), Value (Lakh Rs.), Price (Lakh Rs). Source: Directorate General of Commercial Intelligence and Statistics. 2014 [23].

Table 5. Country wise Tea exports and price growth rates during 1990-2012 (\%).

\begin{tabular}{|c|c|c|c|c|c|c|c|c|c|c|c|c|}
\hline \multirow{3}{*}{ Country } & \multicolumn{12}{|c|}{ Tea Growth rates and cv } \\
\hline & \multicolumn{4}{|c|}{$1996-1997$ to $2003-2004$} & \multicolumn{4}{|c|}{ 2003-2004 to 2013-2014 } & \multicolumn{4}{|c|}{$1996-1997$ to $2013-2014$} \\
\hline & Qty & $\mathrm{cv}$ & Price & $\mathrm{cv}$ & Qty & $\mathrm{Cv}$ & Price & $\mathrm{cv}$ & Qty & $\mathrm{Cv}$ & Price & $\mathrm{cv}$ \\
\hline USA & 0.3 & 60.5 & 13.5 & 46.5 & 43.6 & 67.0 & 7.8 & 28.3 & 23.9 & 104.0 & 10.1 & 44.2 \\
\hline U ARAB EMTS & -33.6 & 58.7 & 3.8 & 29.9 & 35.2 & 58.1 & 5.0 & 33.5 & 0.9 & 57.4 & 4.5 & 41.1 \\
\hline RUSSIA & 24.3 & 62.0 & -8.9 & 26.0 & 7.8 & 33.2 & 19.6 & 38.9 & 14.3 & 45.2 & 6.9 & 51.3 \\
\hline NETHERLAND & 14.9 & 132.8 & -6.3 & 60.1 & 49.7 & 108.1 & 6.7 & 39.3 & 34.2 & 153.6 & 1.2 & 50.8 \\
\hline FRANCE & -13.5 & 106.2 & 0.1 & 36.8 & 38.0 & 105.2 & 4.6 & 32.8 & 13.9 & 143.5 & 2.7 & 36.6 \\
\hline NEW ZEALAND & -8.1 & 42.6 & -9.0 & 77.2 & 39.0 & 90.0 & 6.5 & 38.6 & 17.2 & 113.9 & -0.2 & 82.8 \\
\hline JAPAN & 28.9 & 111.9 & 15.4 & 51.1 & 64.2 & 119.0 & 3.6 & 41.0 & 48.6 & 152.6 & 8.3 & 49.5 \\
\hline AUSTRALIA & 141.0 & 149.8 & 0.7 & 100.3 & 21.3 & 89.8 & 7.2 & 36.9 & 61.0 & 136.0 & 4.5 & 104.8 \\
\hline KUWAIT & -11.1 & 55.3 & -3.3 & 17.5 & 8.6 & 67.6 & 5.0 & 34.2 & 0.0 & 74.2 & 1.5 & 31.2 \\
\hline Others 141 country & -11.4 & 95.0 & 3.6 & 22.4 & 32.6 & 64.8 & 7.0 & 33.6 & 12.3 & 83.4 & 5.6 & 38.9 \\
\hline
\end{tabular}

Qty (000 tonnes), Value (Lakh Rs.), Price (Lakh Rs). Source: Directorate General of Commercial Intelligence and Statistics. 2014 [23]. 
Table 6. Export elasticity's of India's Tea \& Coffee during 1990-2012 (\%).

\begin{tabular}{cccc}
\hline \multirow{3}{*}{ Crop } & \multicolumn{3}{c}{ Elasticity } \\
\cline { 2 - 4 } & 1990-91 to 2000-01 & $2000-01$ to 2011-12 & $1990-91$ to 2011-12 \\
\hline Tea & -7.8 & 19.7 & 13.5 \\
Coffee & 53.5 & 17.0 & 61.4 \\
\hline
\end{tabular}

Table 7. Export elasticity's of India's Coffee during 1990-2012 (\%).

\begin{tabular}{cccc}
\hline \multirow{2}{*}{ Country } & \multicolumn{3}{c}{ Coffee Elasticity } \\
\cline { 2 - 4 } & 1996-1997 to 2003-2004 & 2003-2004 to 2013-2014 & 1996-1997 to 2013-2014 \\
\hline RUSSIA & 9.12 & -1.99 & -25.33 \\
SAUDI ARAB & -0.38 & 1.13 & 1.77 \\
AUSTRALIA & -0.31 & 0.68 & 1.00 \\
USA & 8.55 & -1.20 & -13.38 \\
ITALY & -0.68 & 0.60 & 1.39 \\
JAPAN & 2.08 & -14.81 & -49.68 \\
FRANCE & -0.80 & -1.35 & 1.27 \\
GERMANY & -0.13 & 0.37 & 0.77 \\
KUWAIT & -0.44 & 0.54 & 1.21 \\
UK & -0.78 & 0.35 & 1.57 \\
\hline
\end{tabular}

Table 8. Export elasticity's of India's Tea during 1990-2012 (\%).

\begin{tabular}{cccc}
\hline \multirow{2}{*}{ Country } & \multicolumn{3}{c}{ Tea Elasticity } \\
\cline { 2 - 4 } & $1996-1997$ to & 2003-2004 to 2013-2014 & 1996-1997 to 2013-2014 \\
\hline AUSTRALIA & $2003-2004$ & 1.70 & 1.90 \\
BELGIUM & 28.21 & 1.97 & 1.43 \\
GERMANY & 1.00 & -4.88 & 1.00 \\
U ARAB & -72.21 & 2.45 & 0.26 \\
EMTS & 0.03 & 1.84 & 1.21 \\
U S A & 4.87 & 1.46 & -0.01 \\
KUWAIT & -272.25 & 2.64 & 2.42 \\
FRANCE & -3.49 & 2.65 & 0.99 \\
SINGAPORE & -0.38 & 1.42 & 3.93 \\
U K & 0.87 & 2.05 & -34.58 \\
NEW & & & \\
ZEALAND & & & \\
\hline
\end{tabular}

ing 1996-1997 to 2013-2014, Saudi Arabia has the highest elasticity (1.77) followed by UK (1.57), Italy (1.39), and France (1.27). This indicates that India should export Coffee to these overseas markets compare to other countries. India has comparative advantage to export to Middle East and Europe markets.

The Tea export elasticity's for different overseas markets are in Table 8. During 1996-1997 to 2013-2014, UK has the highest elasticity (3.93), followed by 
France (2.42), and Australia (1.90). This indicates that India should export Tea to these overseas markets. Tea is export commodity for developed countries.

\subsection{Export Destinations}

India's Tea and Coffee export destinations and their share in the world exports during 1990-1991 to 2011-2012 are shown in Table 9 to Table 10. India exports these commodities to ranges from 40 to 150 countries of the world. For each commodity, the countries classified in to the top 10 countries which accounted major share of exports and rest as other countries. Finally, it was found that the

Table 9. India's Coffee export destinations in the world during 1990-2012.

\begin{tabular}{ccccc}
\hline \multicolumn{5}{c}{ Coffee Export Data } \\
\hline Country & Total & Total \% Qty & Total & Total\% of Value \\
\hline ITALY & $863,716.4$ & 28.24 & $780,337.6$ & 28.73 \\
GERMANY & $424,322.7$ & 13.88 & $392,961.4$ & 14.47 \\
BELGIUM & $231,031.5$ & 7.56 & $217,089.9$ & 7.99 \\
SPAIN & $157,941.5$ & 5.16 & $109,618.5$ & 4.04 \\
USA & $121,833.6$ & 3.98 & $89,178.78$ & 3.28 \\
JORDAN & $69,789.23$ & 2.28 & $82,742.1$ & 3.05 \\
SLOVENIA & $106,903.7$ & 3.50 & $79,262.15$ & 2.92 \\
GREECE & $80,660.66$ & 2.64 & $59,953.72$ & 2.21 \\
RUSSIA & $85,979.28$ & 2.81 & $76,202.74$ & 2.81 \\
NETHERLAND & $63,141.38$ & 2.06 & $50,642.7$ & 1.86 \\
Others 130 country \% & $852,646.5$ & 27.88 & $777,892.2$ & 28.64 \\
\hline
\end{tabular}

Source: Directorate General of Commercial Intelligence and Statistics. 2014 [23].

Table 10. India's Tea export destinations in the world during 1990-2012.

\begin{tabular}{ccccc}
\hline \multicolumn{5}{c}{ Tea Export data } \\
\hline Country & Total Qty & Total \% of Qty & Total & Total value of $\%$ \\
\hline AUSTRALIA & $26,109.92$ & 18.62 & $46,468.37$ & 19.35 \\
USA & $22,346.14$ & 15.94 & $43,493.13$ & 18.11 \\
RUSSIA & $24,306.87$ & 17.33 & $39,981.78$ & 16.65 \\
POLAND & 5803.65 & 4.14 & 9970.51 & 4.15 \\
IRAQ & $10,682.58$ & 7.62 & 9054.68 & 3.77 \\
ISRAEL & 3770.2 & 2.69 & 7968.27 & 3.32 \\
UK & 4725.23 & 3.37 & 7376.22 & 3.07 \\
JAPAN & 3162.81 & 2.26 & 7279.1 & 3.03 \\
KAZAKHSTAN & 2900.87 & 2.07 & 5206.13 & 2.17 \\
SAUDI ARAB & 2879.27 & 2.05 & 4982.18 & 2.07 \\
Total 140 Country $\%$ & $33,534.64$ & 23.9 & $58,340.51$ & 24.3 \\
\hline
\end{tabular}

Source: Directorate General of Commercial Intelligence and Statistics. 2014 [23]. 
top 3 countries which accounted $55 \%$ to $60 \%$ of India's exports.

The major destinations for Indian Tea is Australia (18.67\%), Russia (17.33\%) USA (15.94\%), for Coffee Italy (28.73\%), Germany (13.88), Belgium (7.56\%). India has comparative advantage exporting Tea and Coffee to developed countries. This finding is also confirming with elasticity's, export and price growth rates.

\subsection{Global Supply Chains}

\subsubsection{Horticultural Export-Import Companies}

Indian the top leading modern horticultural export and import companies are wide Table 11. These leading company's exports fruits, vegetables, cocoa, coconut, coir, herbal plants, medicinal plants and organic products and wide range of products to Middle East and throughout the globe.

\subsubsection{Market Players in Horticulture Global Supply Chains}

The agents and their role in modern horticultural global supply chain have shown in Table 12. The global supply chain mainly includes producers - exporters - Importers - super markets - consumers. The major market players are exporters, importers and super markets. The producers produce horticultural commodities with high input system and good agricultural practices and sell to exporter. Exporters play major role of processing, packing, storage, and transport to importer. Exporters also do enforcement of procedures, safety and standard issues. Importer buys the product and does trading activity to super markets. Finally, supermarkets will supply commodities to consumer.

\subsubsection{Indian Horticultural Commodities Global Supply Chains}

The forward linkages of producers to exporters in India and backward linkages of importer to consumers in importing countries channels are discussed in this section. The Flow of Indian horticultural commodities to Europe, UK and US Shown in Figure 1 and to Middle East shown in Figure 2 and to South Asia, Africa and South East Asia shown in Figure 3. The supply chain channel to Europe, UK, US shows that growers - exporter - importer - supermarket - consumer. It is highly developed model and no middlemen involved in importing countries. Similarly, the same type of channel found for Middle East countries. In case of South Asia, Africa and South East Asia importing countries supply chain channels lengthy and middlemen involved. The farmers in Developed countries like UK, US, Europe felt the importance of connecting directly customers of domestic and exporters. This helped them to avoid middlemen as these are no way useful in value addition, quality and economic gains. Scientific, planned and organizing came to fore see and predict market signals and demand and supply position in international and local markets. This has increased their income and living standard. South Asia, East Asia, Latin America and Africa (developing countries) the supply channels are lengthy and middlemen are involved. This is major limitation in these countries farmers to realize high income. There is a need to start data harmonization and single window processing. In this connec- 
Table 11. The top leading modern horticulture export and import companies in India.

\begin{tabular}{|c|c|c|c|}
\hline Sl No & Export-Import companies & Place & Role \\
\hline 1 & Gita International & Kolkata - INDIA & Major exporter fresh cut flowers to clients in Middle-east... \\
\hline 2 & Horticultural Impex & $\begin{array}{l}\text { Dehradun - } \\
\text { INDIA }\end{array}$ & $\begin{array}{l}\text { Leading horticulture seed company offering high quality and high yield seeds at market } \\
\text { competitive prices. }\end{array}$ \\
\hline 3 & Royappa Agro International & $\begin{array}{l}\text { Coimbatore - } \\
\text { INDIA }\end{array}$ & $\begin{array}{l}\text { Genuine Manufacturer, Exporter and Supplier of a wide range of products. Exporting } \\
\text { Coco peat(coir) and Supplier of Horticulture imports-exports. }\end{array}$ \\
\hline 4 & Greenvision concepts & $\begin{array}{l}\text { Hyderabad - } \\
\text { INDIA }\end{array}$ & Supplier of Horticulture import \& export, organic farming and sandalwood farming $[+]$ \\
\hline 5 & $\begin{array}{l}\text { Elamgreen export \& import } \\
\text { india private ltd }\end{array}$ & $\begin{array}{l}\text { Pollachi - } \\
\text { INDIA }\end{array}$ & $\begin{array}{l}\text { Established in } 2010 \text {. Traders and Supplier of: Horticulture import-export, coco peat } \\
\text { exporter, coir fiber exporter, fresh coconut exporter, coconut husk and husk chip exporter }\end{array}$ \\
\hline 6 & Greeneem agri pvt ltd & $\begin{array}{l}\text { Virudhunagar - } \\
\text { INDIA }\end{array}$ & $\begin{array}{l}\text { Exporters and Producers of Gree Neem, Neem Oil Bio Pesticide, Neem cake and Supplier } \\
\text { of: Horticulture import-export, organic fertilizers, animal husbandry. }\end{array}$ \\
\hline 7 & Herbalexporters & $\begin{array}{l}\text { Coimbatore - } \\
\text { INDIA }\end{array}$ & $\begin{array}{l}\text { Leading Exporter of Tree herbs, Plants Herbs. Horticulture import-export,| herbs, herbal } \\
\text { plants, herbal exporters and treeherbs. }\end{array}$ \\
\hline 8 & $\begin{array}{l}\text { Abonna fruits and plants co } \\
\text { pvt ltd }\end{array}$ & Siliguri - INDIA & $\begin{array}{l}\text { Leading importer of Berry and Fruit Plants like Blueberry Plants, Blackberry Plants, } \\
\text { Raspberry Plants, Strawberry Plants. And supply these plants in all over India. Supplier of } \\
\text { Horticulture import-export, berries plants, |strawberry plants. }\end{array}$ \\
\hline 9 & Sri vmt agro tech & $\begin{array}{l}\text { Pollachi/coimbat } \\
\text { ore - INDIA }\end{array}$ & $\begin{array}{l}\text { Founded in 2001. leading Manufacturer, Supplier and Exporter of high quality supplier of } \\
\text { Horticulture and import-export coconut fibre, coco peat, coir dust, coir blocks. }\end{array}$ \\
\hline 10 & Milun exports & $\begin{array}{l}\text { Madurai - } \\
\text { INDIA }\end{array}$ & $\begin{array}{l}\text { Founded in 1993. Manufacturer and exporter of Coco peat products. } \\
\text { Coco peat Supplier of Horticulture import-export. }\end{array}$ \\
\hline 11 & Siddha herb inc & Erode-India & $\begin{array}{l}\text { Leading exporters of Moringaoleifera products, Neem products, Spices, herbals, Medicinal } \\
\text { plants and seeds. Supplier of Horticulture - import-export, moringa, neem,| herbals and } \\
\text { medicinal plants. }\end{array}$ \\
\hline 12 & The indian exporters & Sivakasi-India & $\begin{array}{l}\text { Started in 2008, leading manufacturer and supplier of Medical Plants. Supplier of: } \\
\text { Horticulture - import-export, basmati rice, medicinal herbs. }\end{array}$ \\
\hline 13 & Tanishka coir products & Erode - INDIA & $\begin{array}{l}\text { Coconut husk chips, grow medium for horticulture, plants, floriculture, Mashroom } \\
\text { cultivation, soil conditioner. Coco peat, coco pith, husk chips are supplied in form of } 5 \mathrm{~kg} \text {. } \\
\text { Supplier of: Horticulture - import-export, 1-module coffeemaker, coconut husk chips, } \\
\text { coconut fiber, coconut peat. }\end{array}$ \\
\hline 14 & Greenhouse exportters & $\begin{array}{l}\text { Tuticorin - } \\
\text { INDIA }\end{array}$ & $\begin{array}{l}\text { Seller of Coir Pith, Coco Peat, Coir Fiber, Coconut fiber, Coir geotextiles, Coir from India. } \\
\text { Supplier of: Horticulture - import-export, coir geotextiles. }\end{array}$ \\
\hline 15 & Global fruit & $\begin{array}{l}\text { Ahmednagar - } \\
\text { INDIA }\end{array}$ & Supplier of: Horticulture - import-export, fruits and vegetables. \\
\hline
\end{tabular}

Source: http://agriculture-livestock.europages.co.uk/companies/India/Horticulture\%20-\%20import-export.html dated 29-12-2015 [26] [27] [28].

Table 12. The modern horticulture global supply chain players and their role.

\begin{tabular}{cll}
\hline Sl No & Players & \\
\hline 1 & Producer & $\begin{array}{l}\text { High input system e.g. IPM varieties, irrigation } \\
\text { Good Agricultural Practices (GAP) } \\
\text { Some operating out grower schemes }\end{array}$ \\
& Exporters & $\begin{array}{l}\text { Processing, packing, storage, transport, quality assurance system, food safety, human rights, } \\
\text { environmental protection, enforcement of procedures }\end{array}$ \\
3 & Importers & $\begin{array}{l}\text { Buying produce from exporter, store product, trading role } \\
\text { Ensure quality assurance }\end{array}$ \\
& Super markets & Branding, product information, marketing \\
& Consumers & Overseas consumers, USA, UK, Europe, Middle east. \\
& And also South Asia and South East Asia
\end{tabular}




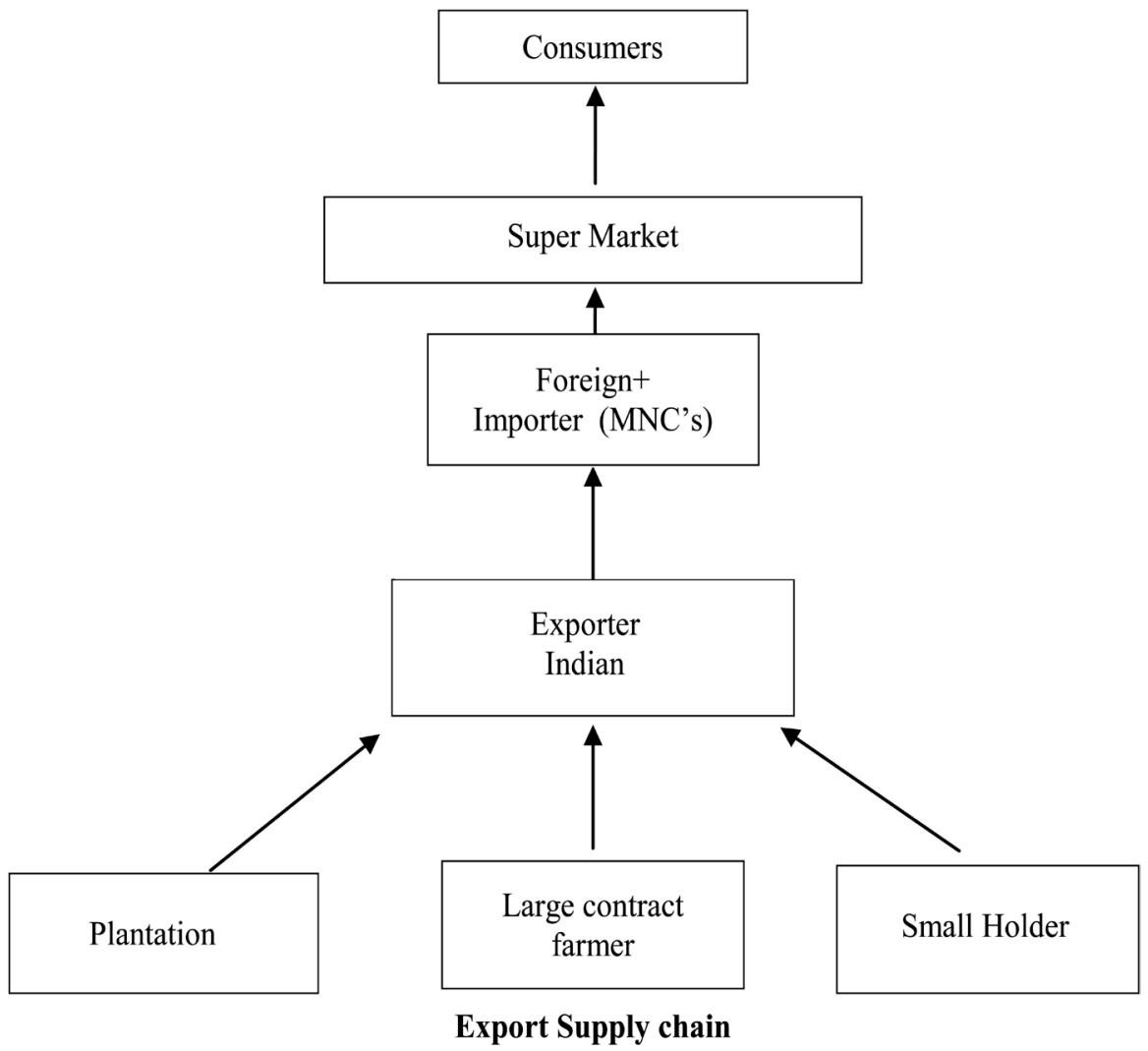

Figure 1. Flow of horticultural commodities from India to/for countries of UK and Europe, US.

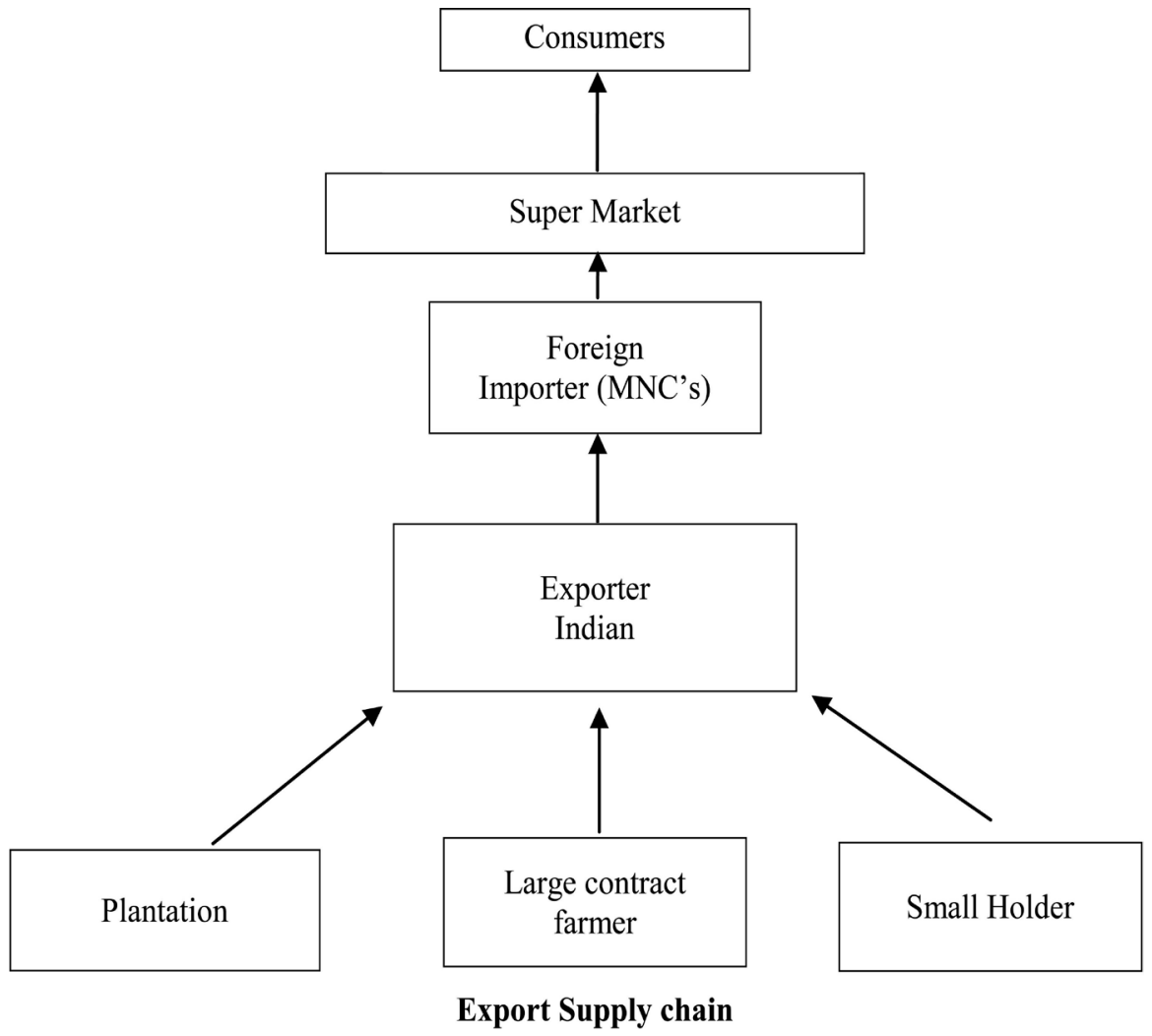

Figure 2. Flow of horticultural commodities from India to/for countries of Middle East. 


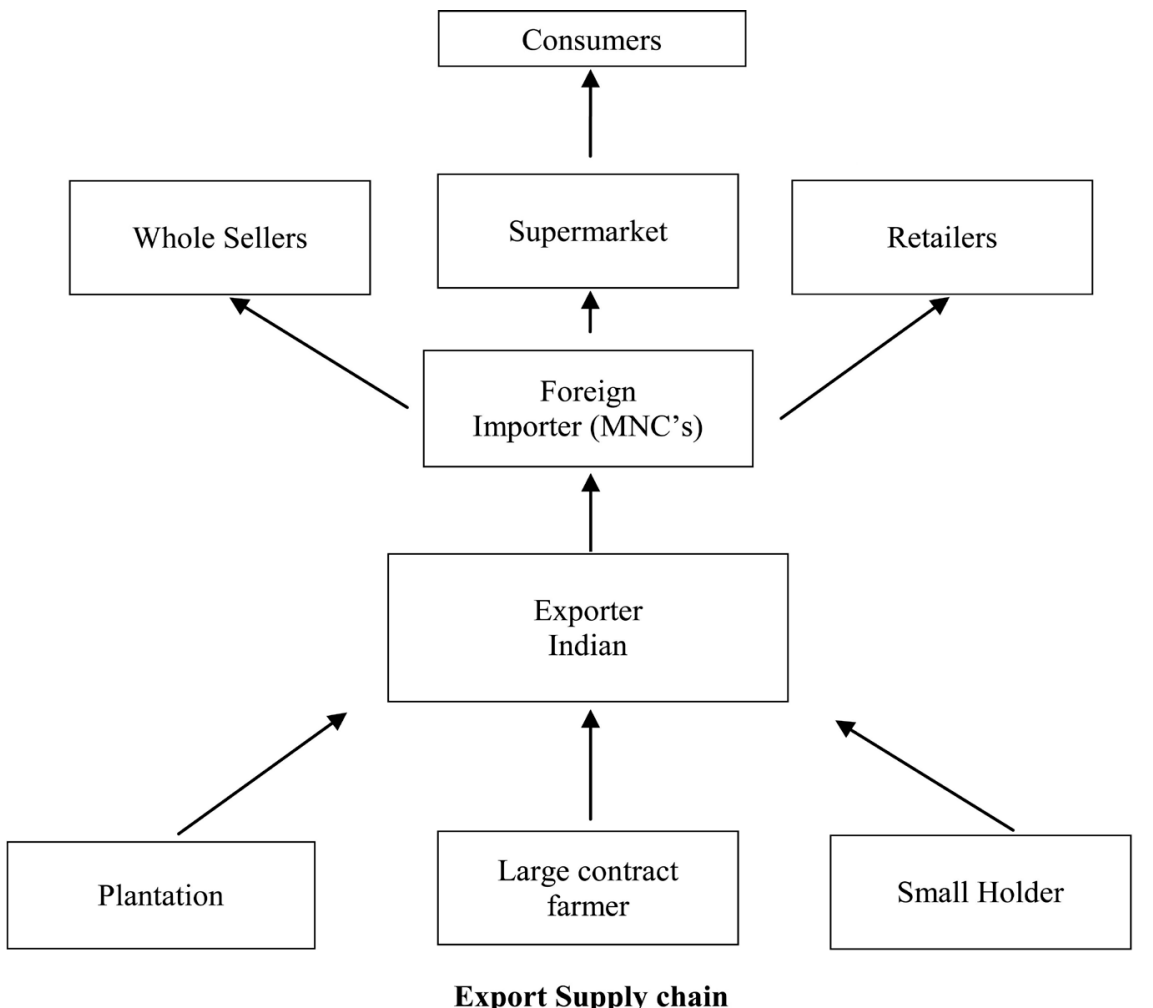

Figure 3. Flow of horticultural commodities from India to/for countries of South Asia, Africa and South East Asia.

tion Digital India will help exporter to access various resources available at government level.

\section{Conclusions}

The study findings were useful in designing policies and programs for escalating exports and foreign income, recognizing profitable destinations and modern export supply chains. The export growth rates during 1990-2012 (\%) of India's fruits, vegetables and flowers are positive except mushroom and walnut. The export growth rates (qty) range from $5.8 \%$ Mango to $19.6 \%$ banana and vegetables; $8.4 \%$ onion to $23 \%$ green chillies and rose export growth rate was $7.8 \%$. Mango, grapes, onion and gherkins exports are stable whereas Banana, Pomegranate, Green chillies and Potato are unstable. During this period the price elasticities of exports of fruits, vegetables and flowers are positive except walnut and mushrooms. This implies that Indian exports of these commodities are highly responsive to price changes in the international markets. Among fruits, the highest elasticity was found for banana (4.58\%) and among vegetables green chillies recorded high (3.98\%). This implies that India should increase exports of these commodities to earn more foreign earnings. Bangladesh, UAE, Pakistan, Malaysia, Sri Lanka, UK, Saudi Arabia, Nepal, Netherland and France are the major destinations $(65 \%$ - 90\%) for Indian fruits. Nepal, UK and France (40\%) are the major destinations for walnut. The major share $50 \%$ to $65 \%$ of India's vegetables (potato, onion, green chilies) are exported to Saudi Arabia, UAE, Pa- 
kistan, Malaysia and UK.

The export growth rates during 1990-2012 (\%) of India's Tea (0.7\%) and coffee $(4.9 \%)$ are positive. The exports of Tea are stable and of Coffee are unstable. During this period the price elasticities of exports of Tea and Coffee are elastic. Among the highest elasticity was found for Coffee (61.4\%) and Tea (13.1\%). During 1996-1997 to 2013-2014, Saudi Arabia has showed the highest coffee export elasticity (1.77) followed by UK (1.57), Italy (1.39) and France (1.27). India has comparative advantage to export to Middle East and Europe markets. While during the same period, UK has showed the highest tea export elasticity (3.93), followed by France (2.42) and Australia (1.90). Tea is export commodity for developed countries. The major destinations which accounted 50\% to $60 \%$ share for Indian Tea and Coffee are Australia, Russia \& USA, Italy, Germany, and Belgium.

India has top leading modern horticultural export and import companies. The supply chain channel to Europe, UK, US shows that highly developed model and no middlemen involved. Similarly, the same type of channel found for Middle East countries. In case of South Asia, Africa and South East Asia importing countries supply chain channels lengthy and middlemen involved. UK, Europe, US (developed countries) farmers connecting with direct customers in domestic markets as well exporters. This eliminated middlemen as they are no use in improving quality and commercial gains.

The study helps in designing agricultural policies and programs to increase horticultural exports and foreign earnings in Asia, Africa and East European markets and USA. India should develop modern supply chains and apply multispeed straggles of exports. Scientific, planned and organizing required to fore see demand and supply position in international and local markets. South Asia, East Asia, Latin America and Africa the supply channels are lengthy and middlemen are involved. In this connection Digital India will help in various export activities. The exporter has an access to various resources available at government level. In the Globalization era the global supply chain model must be connecting producers directly with exporters and importers or consumers of importing countries. This is possible digitalization of data and single window processing.

The international trade in general and export marketing in particular is complex phenomenon because of too many variables effects on trade. This study estimated only few indicators such as elasticities, growth rates, market destinations and traced global supply chains. Hence, future research should be focus on more trade parameters and policies influencing on them.

\section{References}

[1] http://www.prnewswire.com/news-releases/global-horticulture-market-outlook-201 $\underline{5-192285001 . \mathrm{html}}$

[2] Gereffi, G. (1994) The Organisation of Buyer-Driven Global Commodity Chains: How U.S. Retailers Shape Overseas Production Networks. In: Gereffi, G. and Kor- 
zeniewicz, M., Eds., Commodity CŁains and Global Capitalism, Praeger, Westport, 95-122.

[3] Gereffi, G. (1995) Global Production Systems and Third World Development. In: Stallings, B., Ed., Global CŁange, Regional Responses, Cambridge University Press, Cambridge, 100-142.

[4] Tea Board of India (2006) Tea Statistics, Online Database. http://www.teaboard.gov.in/TEABOARDPAGE/MjE5NA

[5] Coffee Board of India (2007) Database on Coffee. http://www.indiacoffee.org/database-coffee.html

[6] World Bank (2001) World Development Report 2000/2001: Attacking Poverty. Oxford University Press. New York. https://openknowledge.worldbank.org/handle/10986/11856

[7] World Bank (2002) World Development Report 2002: Building Institutions for Markets. Oxford, New York. https://openknowledge.worldbank.org/handle/10986/5984

[8] UNCTAD (2009) United Nations Conference on Trade and Development. www.unctad.org/en/PublicationsLibrary/webditctncd2009d1_en.pdf

[9] Singh, K. and Sangla, K. (2012) An Analysis of India's Exports (1991-2006). ZENITH International Journal of Business Economics \& Management Research, 2, 79-108. http://zenithresearch.org.in/images/stories/pdf/2012/Feb/ZIJBEMR/7_ZIJBEMR_V OL2_ISSUE2_FEB2012.pdf

[10] Traill, W.B. (2006) The Rapid Rise of Supermarkets? Development Policy Review, 24, 163-174. https://doi.org/10.1111/j.1467-7679.2006.00320.x

[11] IFPRI (2003) International Food Policy Research Institute Public Policies for Rural Institutions, Markets and Infrastructure Development. MSSD Research Theme. www.ifpri.org/publications

[12] Dastagiri, M.B., Hanumanthaiah, C.V., Paramsivam, P., Sidhu, R.S., Sudha, M., Mandal, S., Singh, B., Chand, K. and Ganesh Kumar, B. (2012) Marketing Efficiency of India's Horticultural Commodities under Different Supply Chains. Out Look on Agriculture, 41, 271-278. https://doi.org/10.5367/oa.2012.0103

[13] Gennaioli, N., Martin, A. and Rossi, S. (2010) Sovereign Default, Domestic Banks and Financial Institutions. CEPR Discussion Papers 7955. https://ideas.repec.org/f/pma513.html

[14] Reardon, T. and Hopkins, R. (2006) The Supermarket Revolution in Developing Countries: Policies to Address Emerging Tensions among Supermarkets, Suppliers and Traditional Retailers. Europeans Journal of Development Research, 18, 522545.

[15] Mithofer, D., Nangole, E. and Asfaw, S. (2008) Smallholder Access to the Export Market: The Case of Vegetables in Kenya. Outlook on Agriculture, 37, 203-211. https://doi.org/10.5367/000000008785915476

[16] Galanopoulos, K., Nilsson, F.O.L., Wajnblom, E. and Surry, Y. (2009) Fruit and Vegetable Production in the New Millennium: Will Mediterranean Production Satisfy Increasing European Demand? Outlook on Agriculture, 38, 235-242. https://doi.org/10.5367/000000009789396784

[17] Dastagiri, M.B., Chand, R., Immanuelraj, T.K., Hanumanthaiah, C.V., Paramsivam, P., Sidhu, R.S., Sudha, M., Mandal, S., Singh, B., Chand, K. and Ganesh Kumar, B. (2013) Indian Vegetables: Production Trends, Marketing Efficiency and Export Competitiveness. American Journal of Agriculture and Forestry, 1, 1-11. https://doi.org/10.11648/j.ajaf.20130101.11 
[18] Lenne, J.M., Pink, D.A.C., Spence, N.J., Ward, A.F., Njuki, J. and Ota, M. (2005) The Vegetable Export System: A Role Model for Local Vegetable Production in Kenya. Outlook on Agriculture, 34, 225-232. https://doi.org/10.5367/000000005775454689

[19] Dastagiri, M.B and Immanuelraj, T.K. (2012) Supermarket Supply Chains in Horticulture in India: The Novel Marketing Models, Effects and Policies. Agrotechnology, $1,107$.

[20] Diego, R.V.C., Buerkert, A. and Schlecht, E. (2011) Economic Benefit to Gardeners and Retailers from Cultivating and Marketing Vegetables in Niamey, Niger. Outlook on Agriculture, 40, 71-78. https://doi.org/10.5367/oa.2011.0027

[21] Gujarati, D.N., Porter, D.C. and Gunasekar, S. (2007) Basic Econometrics. Tata McGraw-Hill Publishing Company, Ltd., New Delhi, 182-183.

[22] Agricultural Produce Export Development Authority (APEDA). Fresh Fruits and Vegetables. http://www.apeda.gov.in/apedawebsite/six_head_product/FFV.htm

[23] Directorate General of Commercial Intelligence and Statistics, Kolkata (DGCIS). India's Export of Principal Commodities. www.dgciskol.nic.in

[24] Export and Import Bank (EXIM BANK). https://www.eximbankindia.in/

[25] Food and Agricultural Organization (FAO). Import and Exports: Commodities by Countries. http://faostat.fao.org/site/342/default.aspx

[26] http://en.wikipedia.org/wiki/Marketing_intelligence

[27] http://financial.thomsonreuters.com/en/products/tools-applications/trading-invest ment-tools/eikon-trading-software/market-analysis-content-features.html?gclid=CI Wcx7rRuMMCFY8rvQodrS0AHg

[28] http://agriculture-livestock.europages.co.uk/companies/India/Horticulture\%20-\%20 import-export.html

\section{Submit or recommend next manuscript to SCIRP and we will provide best service for you:}

Accepting pre-submission inquiries through Email, Facebook, LinkedIn, Twitter, etc. A wide selection of journals (inclusive of 9 subjects, more than 200 journals) Providing 24-hour high-quality service User-friendly online submission system Fair and swift peer-review system Efficient typesetting and proofreading procedure Display of the result of downloads and visits, as well as the number of cited articles Maximum dissemination of your research work

Submit your manuscript at: http://papersubmission.scirp.org/

Or contact me@scirp.org 